\title{
In Vitro Synergistic Antibacterial Activity of Natural Honey Combined with Curcuma Starch and their Correlation with Diastase Number, Flavonoid and Polyphenol Content
}

\author{
Moussa Ahmed $^{1 *}$, Noureddine Djebli² ${ }^{2}$ Saad Aissat1, Kheira Zerrouki ${ }^{3}$ and Akila Bourabeh \\ ${ }^{1}$ Institute of Veterinary Sciences University, Ibn-khaldoun Tiaret (14000), Algeria \\ ${ }^{2}$ Departments of Biology, Faculty of Sciences, Mostaganem University, Algeria \\ ${ }^{3}$ Departments of Biology, Chlef University, Algeria
}

\begin{abstract}
Honey has been acknowledged worldwide as a good source of natural carbohydrates and sweetner. Six honey samples of Apis mellifera forged on plants from western Algeria were analyzed to determine Total Phenolic Content (TPC), Total Flavonoid Content (TFC), Diastase Number (DN), Hydroxy Methyl Furfural (HMF) content and antibacterial activity alone and in combination with Curcuma Starch. The total phenol content was determined by using the Folin-Ciocalteu method, and the flavonoid content was analyzed using by the aluminum chloride method. The HMF and DN were determined by harmonized methods. An agar incorporation technique was used to assess the Minimum Inhibition Concentration (MICs) and Minimum Inhibition Additive Concentration (MIACs) of honey against two strains of Gram-Negative bacteria (Escherchia coli ATCC 25922 and Pseudomonas aeruginosa ATCC 2154). Total phenolic content of honeys ranged from 63.93 to $95.36 \mathrm{mg} \mathrm{GAE} / 100 \mathrm{~g}$ honey, while Total Flavonoid Content (TFC) ranged from 5.41 to $9.94 \mathrm{mg} \mathrm{CE} / 100 \mathrm{~g}$. Hydroxy Methyl Furfural (HMF) content shows values between 3.8 and $78.4 \mathrm{mg} \mathrm{kg}-1$; diastase values were between 7.3 and 26. The MAIC for the six varieties of honeys tested ranged between 12 and $18 \%(\mathrm{vol} / \mathrm{vol})$ and 11 and $15 \%(\mathrm{vol} / \mathrm{vol})$ against $E$. coli and $P$. aeruginosa, respectively. The MIC range for honey alone was $5-70 \%(\mathrm{vol} / \mathrm{vol})$ and $5-40 \%(\mathrm{vol} / \mathrm{vol})$ against $E$. coli and S. aureus, respectively. A positive correlation was observed between total phenolic content and diastase activity $(r=0.248)$ and between diastase activity and total flavonoid content $(r=0.240)$. No clear correlation has been established between the MIC drop and the Diastase Number. The use of curcuma starch allows honey benefit and would constitute a synergetic effect to the antibacterial activity of honey.
\end{abstract}

\section{Introduction}

Microbial infections are the cause of a large burden of diseases and bacteria are listed in the first position among the common microorganisms responsible for opportunistic diseases occurring associated with AIDS. Therapy of bacterial infections is a frequent problem due to the emergence of bacterial strains resistant to numerous antibiotics $[1,2]$. These shortcomings lead to an urgent global call for new antibacterial drugs, particularly from natural resources. Honey is a natural product, well known for thousands of years for its high nutritive value and healing properties. Also Honey has been considered as an important part of traditional medicines since ancient times [3]. Its functions in the treatments of burns, gastrointestinal disorders, asthma, infections, and skin ulcers [4,5]. Honey has an established function as an antibacterial agent that has a broad spectrum of activity against gram-positive and gram negative bacteria [6-8]. More recently maillard reaction products was discovered to contribute to the activity of Canadian honeys [9], bee defensin-1 was detected in a Dutch honey [10] catalase to hydrogen peroxide ratio [11], antibiotic peptides [12], methylglyoxal [13] and melanoidins [9].Phenolic acids and flavonoids in honey have also been found to inhibit the growth of a wide range of Gram-negative and Gram-positive bacteria [14,15]. Honey is a supersaturated solution of sugars, of which fructose $(38 \%)$ and glucose (31\%) are the main contributors, with phenolic compounds, minerals, proteins, free amino acids and vitamins acting as minor components [16]. Also honey contains small amounts of different enzymes, notably, diastase ( $\alpha$ - and $\beta$-amylase), invertase ( $\alpha$-glucosidase), glucose-oxidase, catalase and acid phosphatase, which come from nectar sources, salivary fluids and the pharyngeal gland secretions of the honeybee [17]. A diastase is any one of a group of enzymes that catalyze the breakdown of starch into maltose [18]. Alpha amylase degrades starch to a mixture of the disaccharide maltose, the trisaccharide maltotriose and oligosaccharides known as dextrins. Diastase activity is expressed as the Diastase Number (DN) in Schade units and is defined as follows: one diastase unit corresponds to the enzyme activity of $1 \mathrm{~g}$ of honey, which can hydrolyse $0.01 \mathrm{~g}$ of starch in $1 \mathrm{~h}$ at $40^{\circ} \mathrm{C}$ [19], the activity of this enzyme decreases with the time of storage and that of heating. Alpha amylase inhibitory activity has been reported previously for various plant extracts [20]. The inhibitory effects of polyphenols for $\alpha$-amylases have attracted great interest among researchers [2126]. Tadera et al. [27] tested several flavonoids compounds for their inhibitory activity against $\alpha$-amylase. Also Lo Piparo et al. [28] investigated the interactions between flavonoids and human $\alpha$-amylase in order to understand the molecular requirement for enzyme inhibition. The antimicrobial properties of Algerian honey available on the market differ on account of various factors like geographical and botanical source $[29,30]$. In this study, we evaluated the antibacterial activity of honey combined with curcuma starch and their correlation with diastase number, flavonoid and polyphenol content.

*Corresponding author: Moussa Ahmed, Institute of Veterinary Sciences University, Ibn-khaldoun Tiaret (14000), Algeria, Tel: +213 65234059; E-mail: moussa7014@yahoo.fr

Received November 24, 2012; Accepted December 27, 2012; Published January 01, 2013

Citation: Ahmed M, Djebli N, Aissat S, Zerrouki K, Bourabeh A (2013) In Vitro Synergistic Antibacterial Activity of Natural Honey Combined with Curcuma Starch and their Correlation with Diastase Number, Flavonoid and Polyphenol Content. J Plant Pathol Microb 4:152. doi:10.4172/2157-7471.1000152

Copyright: ( 2013 Ahmed M, et al. This is an open-access article distributed unde the terms of the Creative Commons Attribution License, which permits unrestricted use, distribution, and reproduction in any medium, provided the original author and source are credited. 
Citation: Ahmed M, Djebli N, Aissat S, Zerrouki K, Bourabeh A (2013) In Vitro Synergistic Antibacterial Activity of Natural Honey Combined with Curcuma Starch and their Correlation with Diastase Number, Flavonoid and Polyphenol Content. J Plant Pathol Microb 4:152. doi:10.4172/21577471.1000152

Page 2 of 5

\section{Materials and Methods}

\section{Honey samples}

A total of 6 honey samples were collected from various botanical and geographical sources in Algeria were collected from bee keepers and obtained from local markets. All samples were transferred to the laboratory, stored in amber flasks, and kept at $4^{\circ}-5^{\circ} \mathrm{C}$ until analysis.

\section{Preparation of the stock starch solution}

The stock starch solution was prepared by dissolving $0.5 \mathrm{~g}$ of dried soluble starch in deionised water in a volumetric flask. After heating and stirring the solution for approximately ten minutes, starch was completely dissolved, and the volumetric flask was filled with deionised water to the mark.

\section{Diastase activity (Diastase number)}

The determination of Diastase activity or Diastase Number (DN) was carried out according to Phadebas method recommended by Harmonized methods of the International Honey Commission [31]. An insoluble blue dyed cross-linked type of starch is used as the substrate. This is hydrolyzed by the enzyme, yielding blue water-soluble fragments, determined photometrically at $620 \mathrm{~nm}$. The absorbance of the solution is directly proportional to the diastatic activity of the sample. The diastase activity, expressed as $\mathrm{DN}$ or diastase number, was calculated from the absorbance measurements using Eqs. (1) and (2) for high (8-40 diastase units) and low (up to 8 diastase units) activity values, respectively:

$\mathrm{DN}=28.2 \times \Delta \mathrm{A} 620-2.64$

$\mathrm{DN}=35.2 \times \Delta \mathrm{A} 620-0.46$

\section{Hydroxymethylfurfural (HMF)}

Hydroxymethylfurfural (HMF) was detected using a technique based on the method described by Winkler [32]. Five grams of honey were dissolved, without heating, in oxygen free distilled water and transferred to a $125 \mathrm{ml}$ graduated flask and diluted to volume with oxygen free distilled water. Two milliliters of honey solution was pipetted into two tubes and $5 \mathrm{ml}$ of P-toluidine solution was added to each. Into one test tube, $1 \mathrm{ml}$ of water was pipetted and into the other $1 \mathrm{ml}$ of barbituric acid solution was added; both mixtures were then shaken. Absorbance was read using a spectrophotometer against a blank at a wave length of $550 \mathrm{~nm}$. Calculation: $\mathrm{mg} / 100 \mathrm{~g}$

hydroxymethylfurfural=absorbance/test $\times 192$ [33].

\section{Determination of total phenolic content}

The total phenolic content was determined by the Folin-Ciocalteu (F-C) method [34]. $30 \mathrm{ml}$ of honey solution $(0.1 \mathrm{~g} / \mathrm{ml})$ was mixed with $2.37 \mathrm{ml}$ of milli Q water and $150 \mu \mathrm{l}$ of $0.2 \mathrm{~N}$ Folin-Ciocalteu reagent. The solution was thoroughly mixed by vortexing and incubated for 2 min at ambient temperature. $450 \mathrm{ml}$ of sodium carbonate solution $(0.2$ $\mathrm{g} / \mathrm{ml}$ ) was added to the reaction mixture and further incubated for 2 $\mathrm{h}$ at ambient temperature. The absorbance was measured at $765 \mathrm{~nm}$ using a spectrophotometer. The total phenolic content was determined by comparing with a standard curve prepared using gallic acid (0-200 $\mathrm{mg} / \mathrm{l})$. The mean of at least three readings was calculated and expressed as $\mathrm{mg}$ of gallic acid equivalents (mg GAE)/100 $\mathrm{g}$ of honey.

\section{Total flavonoid content}

The Total Flavonoid Content (TFC) was determined using the aluminium chloride assay according to Amaral et al. [35]. A $10 \mu \mathrm{l}$ volume of a $10 \%(\mathrm{v} / \mathrm{v})$ honey solution was added to the wells of a 96 well plate; then $30 \mu \mathrm{l}$ of a $2.5 \%$ sodium nitrite, $20 \mu \mathrm{l}$ of $2.5 \%$ aluminium chloride solutions and then $100 \mu \mathrm{l}$ of a $2 \%$ sodium hydroxide solution were sequentially added. The samples were mixed well and Abs $450 \mathrm{~nm}$ was measured. TFC was expressed as $\mathrm{mg}$ catechin equivalents (CE)/100 g.

\section{Determination of antibacterial activity}

Bacterial stains: Two Gram-negative Escherchia coli ATCC 25922 and Pseudomonas aeruginosa (ATCC2154). All the strains were cultured at $37^{\circ} \mathrm{C}$ on nutrient agar (NA; Merck, Germany) medium, and the Mueller-Hinton broth medium (MHB; Merck, Germany) has been used in the antibacterial activity assay. All the test microorganisms were purchased from the American Type Culture Collection. The cultures of bacteria were maintained in their appropriate agar slants at $4^{\circ} \mathrm{C}$ throughout the study and used as stock cultures.

Preparation of standard inoculums: Fresh microbial cultures were prepared by streaking loopful of bacterial suspension into organism specific selective media (Merck, Germany) and incubated at optimal temperature in order to maintain approximately uniform growth rate of each organism. The bacterial cultures from fresh media were compared with $0.5 \mathrm{McF}$ arland turbidity standards, which is equivalent to approximately $1 \times 10^{8}$ bacterial cell counts per $\mathrm{ml}$ and it was maintained throughout the experimentation.

\section{MIC and MIAC determinations}

Minimum inhibitory concentration (MIC): Increased concentrations ( $1 \%-50 \% \mathrm{vol} / \mathrm{vol}$ ) were incorporated in to media to test their efficiency against $P$. aeruginosa and $E$. coli. Each plate with final volume of honey and media of $5 \mathrm{ml}$ was inoculated and incubated at $37^{\circ} \mathrm{C}$ for $48 \mathrm{~h}$. The MIC was determined by finding the plates with the lowest concentration of honey on which the strain would not grow. All MIC values were expressed in \% (vol/vol).

Minimum additive inhibitory concentration (MAIC): To evaluate the effect of starch on the antifungal action of honey, $1 \%$ starch solution was prepared using sterile water. Different volumes from the stock solution were added to arrange of honey concentrations lower than the MIC. The same volume of starch solution that has given inhibition with honey was added alone to media as control to check whether or not starch alone has an inhibition effect against $P$. aeruginosa and E. coli. An equivalent volume of water was added to honey instead of starch solution to confirm that additive inhibition is not due to the dilution of honey. The final volume in each plate was $5 \mathrm{ml}$. Starch content in media ranged between $1 \%$ and $8 \%$ (wt/vol). Honey and starch as well as honey and water were incubated for $24 \mathrm{~h}$ at $37^{\circ} \mathrm{C}$ before being incorporated into media. Plates were inoculated and incubated at $37^{\circ} \mathrm{C}$ for $24 \mathrm{~h}$ bioassay was performed in duplicate and repeated twice.

\section{Statistical analysis}

Analyses were made in triplicate, and the data are presented as mean \pm standard deviation. Correlations were established using Pearson's correlation coefficient $(r)$ in bivariate linear correlations $(p<0.01)$. All statistical analyses were performed with the Statistica 7.0 software for Windows.

\section{Results and Discussion}

Diastase activity and HMF are widely recognized as parameters for the evaluation of honey freshness and/or overheating. International regulations set a minimum value of 8 on Gothe's scale for diastase 
Citation: Ahmed M, Djebli N, Aissat S, Zerrouki K, Bourabeh A (2013) In Vitro Synergistic Antibacterial Activity of Natural Honey Combined with Curcuma Starch and their Correlation with Diastase Number, Flavonoid and Polyphenol Content. J Plant Pathol Microb 4:152. doi:10.4172/21577471.1000152

Page 3 of 5

activity, and a maximum HMF content of $40 \mathrm{mg} \mathrm{kg}^{-1}$. The mean of HMF was found $31.2 \mathrm{mg} / \mathrm{kg}$ with the range of 7.68 to $52.6 \mathrm{mg} / \mathrm{kg}$ (Table 1). One of the samples (H1) showed levels of HMF higher than the allowed limits of $40 \mathrm{mg} / \mathrm{kg}$, which are indicative of temperature abuse during processing and/or bad storage practices. Several factors influence HMF levels, such as temperature and time of heating, storage conditions, $\mathrm{pH}$ and floral source, so it provides an indication of overheating and storage in poor conditions [36]. The mean of diastase activity was 9.80 in all samples (Table 1). The variation in the activity of diastases and HMF may be related to source of honey as well as climate of region [37]. Polyphenols are an important group of compounds which influence the appearance and the functional properties of honey [38]. The total phenolic content (mg GAE/100 $\mathrm{g}$ of honey) of Algerian honeys was found in the range of 63.93 to 95.36 (Table 1) which was determined using gallic acid as standard $\left(\mathrm{R}^{2}=0.9988\right)$. A similar level of phenolic content was also observed for Romanian honeydew honeys for which the phenolic content varied from 23.0 to $125.0 \mathrm{mg}$ GAE/100 $\mathrm{g}$ [39]. The concentration of polyphenols varies in honeys of different botanical origin and ranges from 46.0 to $456 \mathrm{mg} / \mathrm{j} / \mathrm{kg}$ [40] and is major factors responsible for biological activities, including antioxidant, antimicrobial, antiviral and anticancer activities [41]. The TFC of honey samples ranged from 5.41 to $9.94 \mathrm{mg} \mathrm{CE} / 100 \mathrm{~g}$ and these values are higher than that of $0.25-8.38 \mathrm{mg} \mathrm{CE} / 100 \mathrm{~g}$ as reported for Brazilian honeys [42]. Flavonoid contents in Burkina Faso honey samples studied by Meda et al. [43] were $0.17-8.35 \mathrm{mg} \mathrm{CE} / 100 \mathrm{~g}$ of honey. In samples from Chile, flavonoid content ranged from 0.014 to $13.8 \mathrm{mg}$ $\mathrm{CE} / 100 \mathrm{~g}$ of honey [44]. In the analysis of Algerian honey samples, a low correlation $(\mathrm{r}=0.878)$ (Table 3 ) between the total flavonoid and total phenolic contents was observed. Islam et al. [42] also described a low correlation $(\mathrm{r}=0.959)$ between the total amount of flavonoids and the total amount of phenolic compounds.

The antibacterial properties of honey have been reviewed

\begin{tabular}{|l|c|c|c|c|c|c|c|c|}
\hline & \multicolumn{2}{|c|}{$\begin{array}{c}\text { Phenolics } \\
\text { (mg Gallic acid/kg) }\end{array}$} & \multicolumn{2}{c|}{$\begin{array}{c}\text { Flavonoids } \\
\text { (mg Catechin/kg) }\end{array}$} & \multicolumn{2}{c|}{$\begin{array}{c}\text { Diastase Number } \\
\text { (Schade Number }\end{array}$} & \multicolumn{2}{c|}{$\begin{array}{c}\text { HMF } \\
\text { (mg/kg) }\end{array}$} \\
\cline { 2 - 10 } & Mean & DS & Mean & DS & Mean & DS & Mean & DS \\
\hline H1 & 85.62 & 2.75 & 9.81 & 0.07 & 15.1 & 2.8 & 78.4 & 1.9 \\
\hline H2 & 95.36 & 6.08 & 9.48 & 0.20 & 23.5 & 2.8 & 28.2 & 1.9 \\
\hline H3 & 82.85 & 14.24 & 9.94 & 0.54 & 11 & 2.8 & 11.1 & 1.9 \\
\hline H4 & 65.31 & 1.60 & 7.10 & 0.04 & 26 & 2.8 & 9.8 & 1.9 \\
\hline H5 & 64.29 & 1.55 & 5.41 & 0.04 & 7.3 & 2.8 & 7.6 & 1.9 \\
\hline H6 & 63.93 & 0.11 & 6.97 & 0.00 & 16.4 & 2.8 & 3.8 & 1.9 \\
\hline
\end{tabular}

*Schade number corresponds to Gothe number or $0.01 \mathrm{~g}$ starch hydrolysed $1 \mathrm{~h}$ at $40^{\circ} \mathrm{C}$ per $1 \mathrm{~g}$ honey.

HMF: Hydroxymethylfurfural.

Table 1: Total polyphenol content (TP), total flavonoids content (TFC), diastase Number and HMF results represent the average of four measurements $\pm S D(n=3)$.

\begin{tabular}{|c|c|c|c|c|c|c|}
\hline \multirow{2}{*}{$\begin{array}{c}\text { Honey } \\
\text { samples }\end{array}$} & \multicolumn{2}{|c|}{ Honey only } & \multicolumn{3}{c|}{ Curcuma starch and honey } \\
\cline { 2 - 8 } & $\begin{array}{c}\text { E. coli } \\
\text { ATCC 25922 }\end{array}$ & $\begin{array}{c}\text { P. aeruginosa } \\
\text { ATCC 2154 }\end{array}$ & $\begin{array}{c}\text { E. coli } \\
\text { ATCC 25922 }\end{array}$ & \multicolumn{2}{|c|}{$\begin{array}{r}\text { P. aeruginosa } \\
\text { ATCC 2154 }\end{array}$} \\
\cline { 2 - 8 } & $\begin{array}{c}\text { MICs \% } \\
\text { (vol/vol) }\end{array}$ & $\begin{array}{c}\text { MICs \% } \\
(\text { vol/vol })\end{array}$ & $\begin{array}{c}\text { MIACs \% } \\
\text { (vol/vol) }\end{array}$ & $\begin{array}{c}\text { MIC } \\
\text { drop\% }\end{array}$ & $\begin{array}{c}\text { MIACs \% } \\
\text { (vol/vol) }\end{array}$ & $\begin{array}{c}\text { MIC } \\
\text { drop\% }\end{array}$ \\
\hline H1 & 16 & 12 & 12 & 25 & 11 & 8.33 \\
\hline H2 & 14 & 12 & 12 & 14.28 & 11 & 8.33 \\
\hline H3 & 20 & 16 & 18 & 10 & 15 & 6.25 \\
\hline H4 & 16 & 14 & 14 & 12.5 & 13 & 7.14 \\
\hline H5 & 16 & 12 & 14 & 12.5 & 11 & 8.33 \\
\hline H6 & 10 & 12 & 09 & 10 & 11 & 8.33 \\
\hline
\end{tabular}

Table 2: Minimum inhibitory concentration (MIC), minimum additive inhibitory concentration (MAIC) and minimum inhibitory concentration drop (MIC drop) of tested honeys.

\begin{tabular}{|c|c|c|c|c|}
\hline Phenolics & 1.000 & $0.878^{*}$ & $0.248^{*}$ & $0.577^{*}$ \\
\hline Flavonoids & $0.878^{*}$ & 1.000 & $0.240^{*}$ & $0.585^{*}$ \\
\hline $\begin{array}{c}\text { Diastase } \\
\text { Number }\end{array}$ & $0.248^{*}$ & $0.240^{*}$ & 1.000 & 0.137 \\
\hline HMF & $0.577^{*}$ & $0.585^{*}$ & 0.137 & 1.000 \\
\hline
\end{tabular}

$\left({ }^{*}\right)$ Significant $P$ values $(P<0.01)$

Table 3: Correlation showing the interrelation among phenolics, flavonoids, diastase number and HMF.

\begin{tabular}{|c|c|c|c|c|}
\hline & Phenolics & Flavonoids & Diastase Number & HMF \\
\hline $\begin{array}{c}\text { MIC drop } \\
\text { E. coli ATCC 25922 }\end{array}$ & $0.437^{*}$ & $0.414^{*}$ & 0.042 & $0.978^{*}$ \\
\hline $\begin{array}{c}\text { MIC drop } \\
\text { P. aeruginosa ATCC 2154 }\end{array}$ & -0.013 & $-0.308^{*}$ & 0.009 & $0.325^{*}$ \\
\hline
\end{tabular}

$\left(^{*}\right)$ Significant $P$ values $(P<0.01)$

Table 4: Pearson's correlation coefficients obtained when correlations between MIC drop honey and different characteristics of honey were studied.

extensively during the last years in multiple studies all over the world. The results of our work indicated that the six varieties of honeys tested have an antibacterial property. The intensity of effect on the growth of germs, varied according to the botanical honey origin and the type of germ tested. As a whole, the six varieties presented antibacterial activities against $E$. coli at concentrations from 14 to $20 \%$ (vol/vol) and 12 to $16 \%$ (vol/vol) for P. aeruginosa (Table 2). When starch was incubated with honey and added to media, a MIC drop was noticed with each variety and the MAICs of the six varieties ranged between 11 to $15 \%$ and 9 to $18 \%(\mathrm{vol} / \mathrm{vol}$ ) (Table 2). The inhibitory action was seen neither in the media containing starch only nor in media with water and starch. Infection with $P$. aeruginosa is the most serious complication in burns patients $[45,46]$, followed by infections with $E$. coli and other pathogen microorganisms [45]. With increasing interest in the use of alternative therapies and as the development of antibiotic resistant bacteria spreads. Many works was interested, during this last decade, with the products of the hive and in particular honey, efficient product against the germs secreted by the bees as a possible source of new pharmaceutical and medical agent. Honey saturated or super-saturated sugar, containing about 95\% sugars [47]. Such a high concentration of sugar has antimicrobial activity since it cause osmotic stress $[48,49]$. The high osmolarity of honey is due to the high content of sugar (average over $85 \%$ of honey) including fructose, glucose, maltose, sucrose and other types of carbohydrates [50]. Sugar paste was reported as being used successfully in 605 patients with wounds, burns and ulcers, with lower requirements for skin grafting, antibiotics, and lower hospital costs [51]. Recent experimental finding indicated that the ginger and potato starch and amylase present in honey increases the osmotic effect in the media by increasing the amount of sugars and consequently increasing the antimicrobial activity [52-55]. In recent years, a large number of studies have been done on the antibacterial activity of phenolic compounds of natural origin. Phenolics compounds of honey have been shown to exhibit antibacterial activities [16, 56-58]. Davidson et al. [59] have shown that individual phenolic compounds have growth inhibition on a wide range of Gram-positive and Gramnegative bacteria. But Ulusoy et al. [60] found that antimicrobial activity was not linearly correlated with total and individual phenolic compounds. In the present study, the relationship between phenolic, Flavonoids content, HMF and the MIC drop of honey was observed (Table 4). No correlation has been established between the MIC drop and the Diastase Number.

Honey is one of the natural products widely used to treat infections 
Citation: Ahmed M, Djebli N, Aissat S, Zerrouki K, Bourabeh A (2013) In Vitro Synergistic Antibacterial Activity of Natural Honey Combined with Curcuma Starch and their Correlation with Diastase Number, Flavonoid and Polyphenol Content. J Plant Pathol Microb 4:152. doi:10.4172/21577471.1000152

that resist conventional drugs. But its price makes it an unaffordable substance in developing countries. Our results show that adding starch to honey could contribute to reducing the quantity of honey to be used without losing the expected effect. In the present study, the antibacterial activity of honey on E. coli and P. aeruginosa strains were confirmed and synergism was possible with curcuma starch tested. These data encourage further in vivo studies to validate these interesting results before clinical trials can proceed.

\section{References}

1. Keasah C, Odugbmi T, Ben Redjeb S, Boye CS, Dosso M (1998) The Members of Palm Project. Prevalence of Methicillin-Resistant Staphylococcus aureus in Eight African Hospitals and Malta. Poster E.093, 38th ICAAC, San Diego, USA.

2. Otsuki M, Nishino T (2000) Report of questionnaire survey for methicillinresistant Staphylococcus aureus and penicillin-resistant Streptococcus pneumoniae in the Kinki district. Kansenshogaku Zasshi 74: 658-663.

3. White JW Jr (1979) Methods for determining carbohydrates, hydroxymethylfurfural, and proline in honey: collaborative study. J Assoc Off Anal Chem 62: 515-526.

4. Orhan F, Sekerel BE, Kocabas CN, Sackesen C, Adalioglu G, et al. (2003) Complementary and alternative medicine in children with asthma. Ann Allergy Asthma Immunol 90: 611-615.

5. Silva LR, Videira R, Monteiro AP, Valentao P, Andrade PB (2009) Honey from Luso region (Portugal): Physicochemical characteristics and mineral contents. Microchem J 93: 73-77

6. Moussa A, Noureddine D, Mohamed HS, Abdelmelek M, Saad A (2012) Antibacterial activity of various honey types of Algeria against Staphylococcus aureus and Streptococcus pyogenes. Asian Pac J Trop Med 5: 773-776.

7. Moussa A, Noureddine, Abdelmelek M, Saad A (2012) Antibacterial activity of various honey types of Algeria against pathogenic gram-negative bacilli: Escherichia coli and Pseudomonas aeruginosa. Asian Pacific Journal of Tropical Disease 2: 211-214.

8. Lusby PE, Coombes A, Wilkinson JM (2002) Honey: a potent agent for wound healing? J Wound Ostomy Continence Nurs 29: 295-300.

9. Brudzynski K, Miotto D (2011) Honey melanoidins: Analysis of the compositions of the high molecular weight melanoidins exhibiting radical-scavenging activity. Food Chem 127: 1023-1030.

10. Kwakman $\mathrm{PH}$, te Velde AA, de Boer L, Speijer D, Vandenbroucke-Grauls CM, et al. (2010) How honey kills bacteria. FASEB J 24: 2576-2582.

11. Weston RJ (2000) The contribution of catalase and other natural products to the antibacterial activity of honey: a review. Food Chem 71: 235-239.

12. Kwakman PHS, de Boer L, Ruyter-Spira CP, Creemers-Molenaar T, Helsper JP, et al. (2011) Medical-grade honey enriched with antimicrobial peptide has enhanced activity against antibiotic resistant pathogens. Eur J Clin Microbio Infect Dis 30: 251-257.

13. Adams JC, Boult CH, Deadman BJ, Farr JM, Grainger MN, et al. (2008) Isolation by HPLC and characterization of the bioactive fraction of New Zealand manuka (Leptospermum scoparium) honey. Carbohydr Res 343: 651-659.

14. Davidson PM (1993) Parabens and phenolic compounds-Antimicrobials in Foods. (2ndedn), Marcel Dekker, New York.

15. Taormina PJ, Niemira BA, Beuchat LR (2001) Inhibitory activity of honey against foodborne pathogens as influenced by the presence of hydrogen peroxide and level of antioxidant power. Int J Food Microbiol 69: 217-225

16. Alvarez-Suarez JM, Tulipani S, Diaz D, Estevez Y, Romandini S, et al. (2010) Antioxidant and antimicrobial capacity of several monofloral Cuban honeys and their correlation with color, polyphenol content and other chemical compounds. Food Chem Toxicol 48: 2490-2499.

17. Huidobro JF, Santana FJ, Sanchez MP, Sancho MT, Muniategui S, et al. (1995) Diastase, invertase and $\beta$-glucosidase activities in fresh honey from north-west Spain. J Api Res 34: 39-44.

18. Crane E (1975) Honey: A Comprehensive Survey, International Bee Research Association, Heinemann, London, UK.

19. Sakăc N, Sak-Bosnar M (2012) A rapid method for the determination of honey diastase activity. Talanta 93: 135-138.
20. Sai Kumar RS, Singh SA, Rao AG (2009) Conformational stability of alphaamylase from malted sorghum (Sorghum bicolor): reversible unfolding by denaturants. Biochimie 91: 548-557.

21. Kawakami K, Aketa S, Nakanami M, lizuka S, Hirayama M, et al. (2010) Major water-soluble polyphenols, proanthocyanidins, in leaves of persimmon (Diospyros kaki) and their alpha-amylase inhibitory activity. Biosci Biotechnol Biochem 74: 1380-1385.

22. Shobana S, Sreerama YN, Malleshi NG (2009) Composition and enzyme inhibitory properties of finger millet (Eleusine coracana L.) seed coat phenolics: mode of inhibition of $\alpha$-glucosidase and pancreatic amylase. Food Chem 115 1268-1273.

23. Lee YA, Cho EJ, Tanaka T, Yokozawa T (2007) Inhibitory activities of proanthocyanidins from persimmon against oxidative stress and digestive enzymes related to diabetes. J Nutr Sci Vitaminol 53: 287-292.

24. Xiao J, Kai G, Ni X, Yang F, Chen X (2011) Interaction of natural polyphenols with a-amylase in vitro: molecular property-affinity relationship aspect. Mol Biosyst 7: 1883-1890.

25. McDougall GJ, Shpiro F, Dobson P, Smith P, Blake A, et al. (2005) Different Polyphenolic components of soft fruits inhibit alpha-amylase and alphaglucosidase. J Agric Food Chem 53: 2760-2766.

26. Grussu D, Stewart D, McDougall GJ (2011) Berry polyphenols inhibit a-amylase in vitro: identifying active components in rowanberry and raspberry. J Agric Food Chem 59: 2324-2331.

27. Tadera K, Minami Y, Takamatsu K, Matsuoka T (2006) Inhibition of alphaglucosidase and alpha-amylase by flavonoids. J Nutr Sci Vitaminol 52: 149 153.

28. Lo Piparo E, Scheib H, Frei N, Williamson G, Grigorov M, et al. (2008) Flavonoids for controlling starch digestion: structural requirements for inhibiting human alpha-amylase. J Med Chem 51: 3555-3561.

29. Ahmed Moussa, Djebli Noureddine, Aissat Saad, Meslem Abdelmalek Bacha Salima (2012) The Influence of Botanical Origin and Physicochemical Parameters on the Antifungal Activity of Algerian Honey. J Plant Pathol Microb 3: 5.

30. Moussa A, Noureddine D, Saad A, Abdelmelek M, Abdelkader B (2012) Antifungal activity of four honeys of different types from Algeria against pathogenic yeast : Candida albicans and Rhodotorula sp. Asian Pac J Trop Biomed 2: 554-557.

31. Bogdanov S (2002) Harmonised methods of the international honey commission. Swiss Bee Research Center, Switzerland 1-62.

32. Winkler C (1955) Beitrag Zur Nachweis und Zur Bestimmung Von Kunsthoning Zeitschr Lebensm Unters Forsch 102: 161-167.

33. Auerbach F, Borries G (1924) Auerbach and Borries equation. Z Nahr Genssm 22: 353-358.

34. Singleton VL, Orthofer R, Lamuela Raventos RM (1999) Analysis of total phenols and other oxidation substrates and antioxidants by means of FolinCiocalteau reagent. Methods Enzymol 299: 152-178.

35. Amaral S, Mira L, Nogueira JM, da Silva AP, Helena Florêncio M (2009) Plant extracts with anti-inflammatory properties-A new approach for characterization of their bioactive compounds and establishment of structure-antioxidant activity relationships. Bioorg Med Chem 17: 1876-1883.

36. Fallico B, Arena E, Verzera A, Zappalà M (2006) The European Food Legislation and its impact on honey sector. Accreditation and Quality Assurance 11: 49-54

37. Singh N, Bath PK (1997) Quality evaluation of different types of Indian honey. Food Chem 58: 129-133.

38. Cimpoiu C, Hosu A, Miclaus V, Puscas A (2012) Determination of the floral origin of some Romanian honeys on the basis of physical and biochemical properties. Spectrochim Acta A Mol Biomol Spectrosc 100: 149-154.

39. Al ML, Daniel D, Moise A, Bobis O, Laslo L, et al. (2009) Physicochemical and bioactive properties of different floral origin honeys from Romania. Food Chem 112: 863-867.

40. Gheldof N, Wang XH, Engeseth NJ (2002) Identification and Quantification of Antioxidant Components of Honeys from Various Floral Sources. J Agric Food Chem 50: 5870-5877. 
Citation: Ahmed M, Djebli N, Aissat S, Zerrouki K, Bourabeh A (2013) In Vitro Synergistic Antibacterial Activity of Natural Honey Combined with Curcuma Starch and their Correlation with Diastase Number, Flavonoid and Polyphenol Content. J Plant Pathol Microb 4:152. doi:10.4172/21577471.1000152

41. Al-Mamary M, Al-Meeri A, Al-Habori M (2002) Antioxidant activities and total phenolics of different types of honey. Nutr Res 22: 1041-1047.

42. Islam A, Khalil I, Islam N, Moniruzzaman M, Mottalib A, et al. (2012) Physicochemical and antioxidant properties of Bangladeshi honeys stored for more than one year. BMC Complementary and Alternative Medicine 12: 177.

43. Meda A, Lamien CE, Romito M, Millogo J, Nacoulma OG (2005) Determination of the total phenolic, flavonoid and proline contents in burkina fasan honey, as well as their radical scavenging activity. Food Chem 91: 571-577.

44. Muñoz O, Copaja S, Speisky H, Peña R, Montenegro G (2007) Contenido de flavonoides y compuestos fenólicos de mieles chilenas e índice antioxidante, Quim. Nova 30: 848-851.

45. Nasser S, Mabrouk A, Maher A (2003) Colonization of burn wounds in Ain Shams University burn unit. Burns 29: 229-233.

46. Altoparlak U, Aktas F, Selebi D, Ozkurt Z, Akcay MN (2005) Prevalence of metallo-beta-lactamase among Pseudomonas aeruginosa and Actinobacter baumanii isolated from burn wounds and in vitro activities of antibiotic combinations against these isolates. Burns 31: 707-710.

47. Wang J, Li QX (2011) Chemical Composition, Characterization, and Differentiation of Honey Botanical and Geographical Origins. Adv Food Nutr Res 62: 89-137.

48. Chirife J, Scarmato G, Herszage L (1982) Scientific basis for use of granulated sugar in treatment of infected wounds. Lancet 1: 560-561.

49. Molan PC (1992) The antibacterial nature of honey: 1 . The nature of the antibacterial activity. Bee World 73: 5-28.

50. White W, Jonathan Jr (1975) Physical characteristics of honey. In: Honey: A Comprehensive Survey. Ed. E. Crane, Heinemann, London.

51. Knutson RA, Merbitz LA, Creekmore MA, Snipes HG (1981) Use of sugar and povidone-iodine to enhance wound healing: five year's experience. South Med J 74: 1329-1335.
52. Ahmed M, Djebli N, Aissat S, Douichene S (2012) The Relationship between Fructose, Glucose and Maltose Content with Diastase Number and AntiPseudomonal Activity of Natural Honey Combined with Potato Starch. Organic Chem Curr Res 1: 6

53. Ahmed M, Djebli N, Hammoudi SM, Aissat S, Akila B, et al. (2012) Additive potential of ginger starch on antifungal potency of honey against Candida albicans. Asian Pac J Trop Biomed 2: 253-255.

54. Ahmed M, Djebli N, Aissat S, Aggad H, Boucif Ahmed (2011) Antifungal Activity of a Combination of Algeria Honey and Starch of Ginger against Aspergillus niger. International Journal of Microbiological Research 2: 263-266.

55. Ahmed M, Aissat S, Djebli N, Boulkaboul A, Abdelmalek M, et al. (2011) The Influence of Starch of Ginger on the Antibacterial Activity of Honey of Different Types from Algeria against Escherichia coli and Staphylococcus aureus. International Journal of Microbiological Research 2: 258-262.

56. Estevinho L, Pereira AP, Moreira L, Dias LG, Pereira E (2008) Antioxidant and antimicrobial effects of phenolic compounds extracts of Northeast Portugal honey. Food Chem Toxicol 46: 3774-3779.

57. Silici S, Sagdic O, Ekici L (2010) Total phenolic content, antiradical, antioxidant and antimicrobial activities of Rhododendron honeys. Food Chem 121: 238243.

58. Escuredo O, Silva LR, Valentão P, Seijo MC, Andrade PB (2012) Assessing Rubus honey value: Pollen and phenolic compounds content and antibacterial capacity. Food Chem 130: 671-678.

59. Davidson PM (1993) Parabens and phenolic compounds. In: Davidson PM Branen AL. (ed.), Antimicrobials in Foods. (2ndedn), Marcel Dekker, New York.

60. Ulusoy E, Kolayli S, Sarikaya AO (2010) Antioxidant and antimicrobial activity of different floral origin honeys from turkiye. J Food Biochem 34: 321-335. 